Sel eni um coat ed carbon el ect rode for anodi $c$ st ri ppi ng vol tammet ri c det er mi nat i on of copper ( I I)

\begin{tabular}{|l|l|}
\hline 著者 & NAGAOSA Yuki o, ZONG Pi ng, KAM O Aki hi ro \\
\hline $\begin{array}{l}\text { j our nal or } \\
\text { publ i cat i on t i t l e }\end{array}$ & M crochi mi ca Act a \\
\hline vol une & 167 \\
\hline number & $3-4$ \\
\hline page range & $241-246$ \\
\hline year & $2009-11$ \\
\hline URL & ht t p: //hdl . handl e. net /10098/2827 \\
\hline
\end{tabular}




\section{Selenium-coated carbon electrode for anodic stripping voltammetric determination of copper(II)}

Yukio Nagaosa*, Ping Zong and Akihiro Kamio

Y. Nagaosa $\cdot$ P. Zong $\cdot$ A. Kamio

Department of Applied Chemistry and Biotechnology, Graduate School of Engineering, University of Fukui, Bunkyo, Fukui 910-8507, Japan

e-mail: nagaosa@u-fukui.ac.jp; nagaosa@acbio2.acbio.fukui-u.ac.jp 
Abstract In this work, we describe a new and promising type of selenium film electrode for anodic stripping voltammetry. This method is based on formation of copper selenide onto an in-situ formed selenium-film carbon electrode, this followed by Osteryoung square-wave anodic stripping voltammetry. Copper(II) is also in-situ electroplated in a test solution containing $0.01 \mathrm{~mol} \mathrm{~L}^{-1}$ hydrochloric acid, $0.05 \mathrm{~mol} \mathrm{~L}^{-1}$ potassium chloride and $500 \mu \mathrm{g} \mathrm{L} \mathrm{L}^{-1} \mathrm{Se}(\mathrm{IV})$ at a deposition potential of $-300 \mathrm{mV}$. Well-defined anodic peak current observed at about $200 \mathrm{mV}$ is directly proportional to the $\mathrm{Cu}(\mathrm{II})$ concentration over the range of $1.0-100 \mu \mathrm{g} \mathrm{L}^{-1}$ under the optimized conditions. The detection limit (3 sigma level) is $0.2 \mu \mathrm{g} \mathrm{L}{ }^{-1} \mathrm{Cu}(\mathrm{II})$ at $180 \mathrm{~s}$ deposition time. Relatively less interferences are shown from most of metal ions except for antimony(III). The proposed method can be applied to sample analyses of river water and oyster tissue with good accuracy.

Keywords Selenium-film electrode; stripping analysis; copper determination 


\section{Introduction}

Stripping voltammetry has been accepted to be one of the most sensitive and convenient electrochemical techniques for the determination of heavy metals in aqueous medium at trace concentration levels [1]. Conventionally, hanging mercury drop electrodes and mercury film electrodes [2] have been used as the working electrodes for stripping voltammetric analysis of metals. Due to high toxicity of mercury, much effort has recently been directed into developments of the so-called "mercury-free" electrodes, which include bismuth [3-6], antimony [7,8], lead [9] and tin [10] that have relatively wide potential windows at the negative region depending on the standard redox potentials. Among several kinds of electrode materials developed, the Bi- and Sb-film electrode have been getting more and more recognized as useful and feasible alternatives to the toxic mercury-based electrodes in the direct determination of metals such as $\mathrm{Cd}$ [3], $\mathrm{Pb}$ [3], $\mathrm{Zn}$ [3], In [11], $\mathrm{Tl}$ [11], $\mathrm{Co}$ [12], $\mathrm{Ni}$ [13], As [14] and Se [15] by anodic or cathodic stripping analysis. Several review articles describe the characteristics of the mercury-free electrodes, and their electroanalytical performances and a variety of applications [16-19]. However there is one drawback that the Bi- and Sb-film electrodes have relatively negative anodic limits (around $-0.20 \mathrm{~V} v$ s. $\mathrm{Ag} / \mathrm{AgCl}$ ) restricted by dissolution of the metal electrodes. For example, a considerably large anodic peak due to bismuth dissolution appeared just before the $\mathrm{Cu}(\mathrm{II})$ signal [11] causes difficulties in the determination of $\mathrm{Cu}(\mathrm{II})$ by anodic stripping analysis even when gallium [20,21] or hydrogen peroxide [22] as a modifier of the deposited species was added. In the positive potential ranges, the carbon-based electrodes $[23,24]$ or gold-film electrodes [25] may be rather effective for the anodic stripping analysis of copper(II).

In the past few decades, different kinds of semiconductors comprised of selenium have received a 
great deal of attention due to its particular photoelectrical properties and wide applications in electronic and optoelectronic devices such as the solar cell, super ionic conductors, optical filter, etc. In order to obtain an amorphous layer of semiconductor metal-selenide compound, the electrodeposition (electrosynthesis) and characterization have been studied on carbon or gold electrodes [26-29]. Metal selenides (MSe, where M is a divalent cation) are deposited on the working electrode according to the general reaction $\mathrm{H}_{2} \mathrm{SeO}_{3}+\mathrm{M}^{2+}+6 \mathrm{e}^{-}+4 \mathrm{H}^{+} \rightarrow \mathrm{MSe}+3 \mathrm{H}_{2} \mathrm{O}$ by a mechanism involving $\mathrm{Se}^{2-}$, selenide, selenious (intermediates) to yield elemental selenium. Copper selenides can play a crucial role of the counterpart for the other metals to be deposited. With respect to electrochemistry of metal selenides, the cathodic stripping voltammetric determination of selenium(IV) has been reported using copper-film mercury and copper-modified mercury-film electrodes, based on the formation of copper selenide compounds [30-32].

When selenium(IV) was added to the solution to a larger content to form the film electrode, we must pay much attention to the metal toxicity and to the storage of the wastes from the view point of environmental protection. The average concentration of seawater, $0.09 \mathrm{mg} \mathrm{L}^{-1}$, is higher than that of mercury. US Environmental Protection Agency recommends to conserve a standard value of $0.01 \mathrm{mg}$ $\mathrm{L}^{-1}$ in natural water.

In this article, we report on the polarization character of the in-situ prepared selenium film electrode and its successful application for determining traces of $\mathrm{Cu}(\mathrm{II})$ in $0.01 \mathrm{~mol} \mathrm{~L}^{-1}$ hydrochloric acid solution by Osteryoung square wave anodic stripping voltammetry (OSWASV). Herein, we demonstrate that an in-situ plated selenium-film electrode has been successfully prepared by electroplating technique, and $\mathrm{Cu}(\mathrm{II})$ can be determined by anodic stripping voltammetry following preconcentration technique. Regardless of its poor electronic conducting property, the new type of 
selenium-film electrode can be expected as another "mercury-free" electrode to expand the scope of analytical utilities and applications to trace metal determination in electrochemical stripping analysis.

\section{Experimental}

Reagents

All chemicals used were of analytical reagent grade, and all solutions were prepared with deionized and distilled water. Stock solutions of $\mathrm{Se}(\mathrm{IV})$ and $\mathrm{Cu}(\mathrm{II})$ were individually prepared by diluting 1000 $\mathrm{mg} \mathrm{L}^{-1}$ standards for atomic absorption spectrometry with $0.01 \mathrm{~mol} \mathrm{~L}^{-1}$ hydrochloric acid. The other metal ion solutions were also prepared by diluting their standard solutions $\left(1000 \mathrm{mg} \mathrm{L}^{-1}\right)$ with 0.01 mol L $\mathrm{L}^{-1}$ hydrochloric acid. All stock solutions were stored in a refrigerator at $2{ }^{\circ} \mathrm{C}$.

Apparatus

A BAS Model CV-50W voltammetric analyzer (Bioanalytical system, USA) was employed for measurements of cyclic voltammetry (CV) and OSWASV. Unless otherwise stated, the instrumental settings for OSWASV measurements were as follows: $4 \mathrm{mV}$ step potential; $25 \mathrm{mV}$ square wave amplitude; $15 \mathrm{~Hz}$ frequency; $10 \mathrm{~s}$ equilibrium time. A plastic formed carbon disk (PFC, $3 \mathrm{~mm}$ in diameter) as working electrode substrate was obtained from BAS (Bioanalytical system, Tokyo, Japan). A platinum wire counter electrode and an $\mathrm{Ag} / \mathrm{AgCl}$ (sat. $\mathrm{KCl}$ ) reference electrodes were also 
used.

Experimental procedures

The plastic formed carbon electrode surface was cleaned by polishing with aluminum oxide slurry and cleaned by distilled water and a piece of filter paper. The treated electrode was then immersed in 1.0 mol L $\mathrm{L}^{-1}$ hydrochloric acid for $1 \mathrm{~min}$, and rinsed with water. After each voltammetric measurements, the working electrode was cleaned and reactivated by applying the electrode at $800 \mathrm{mV}$ for $60 \mathrm{~s}$ in 0.1 mol L $\mathrm{L}^{-1}$ hydrochloric acid under stirring.

The established procedures for the determination of $\mathrm{Cu}(\mathrm{II})$ by OSWASV were set as follows: an aliquot $(2.0 \mathrm{~mL})$ of sample solution was introduced into a $15-\mathrm{mL}$ electrochemical cell. The reagent solutions were then added to the standard or sample solution, and the total volume was finally made up to $10.0 \mathrm{~mL}$. The equilibrium concentrations of added reagents except $\mathrm{Cu}(\mathrm{II})$ were adjusted to 0.01 mol L ${ }^{-1}$ hydrochloride acid, $0.05 \mathrm{~mol} \mathrm{~L}^{-1}$ potassium chloride, and $500 \mu \mathrm{g} \mathrm{L} \mathrm{L}^{-1} \mathrm{Se}(\mathrm{IV})$. Nitrogen was purged into the solution for $600 \mathrm{~s}$, and then the $\mathrm{Cu}(\mathrm{II})$ was initially reduced at a potential of $-300 \mathrm{mV}$ for $180 \mathrm{~s}$ under solution stirring. After the stirrer was switched off for $10 \mathrm{~s}$ equilibrium time, the electrode potential was scanned from -300 to $800 \mathrm{mV}$ in the positive direction.

The standard reference material of river water (SRM JSAC 0302-3 from the Japan Society for Analytical Chemistry) was acidified by $0.01 \mathrm{~mol} \mathrm{~L}^{-1}$ hydrochloride acid. The NBS standard reference material (SRM 1566), oyster tissue $(5.00 \mathrm{~g})$, was heated with concentrated nitric acid and hydrochloride acid, and evaporated to almost dryness. The residue was diluted with water $(100 \mathrm{~mL})$ to get appropriate concentrations. The reference material samples were analyzed by standard addition 
and background subtraction method.

\section{Results and discussion}

Voltammetric behavior of copper(II) with a selenium-coated carbon electrode

Preliminary experiments indicated that an anodic response due to $\mathrm{Cu}(\mathrm{II})$ was observed at about 200 $\mathrm{mV}$ vs. $\mathrm{Ag} / \mathrm{AgCl}$ by applying the working electrode to a positive direction following in-situ deposition of copper selenide in presence of excess Se(IV) at $-300 \mathrm{mV}$. Before detailed investigations, the accessible potential range (potential window) of selenium-film carbon electrode was examined by cyclic voltammetric measurements for a blank solution containing $0.01 \mathrm{~mol} \mathrm{~L}^{-1}$ hydrochloric acid and $500 \mu \mathrm{g} \mathrm{L}^{-1} \mathrm{Se}(\mathrm{IV})$ over the potential range from -400 to $800 \mathrm{mV}$ (Fig. 1). Since the reduction of $\mathrm{Se}(0)$ to $\mathrm{Se}(-\mathrm{II})$ appeared as $\mathrm{H}_{2} \mathrm{Se}$ occur at potentials lower than $-600 \mathrm{mV}$ on a PFC substrate, the cathodic limit was set by the hydrogen generation wave. On the other hand, the anodic limit of Se-film carbon electrode, $400 \mathrm{mV}$, was set by the oxidation of reduced $\mathrm{Se}(0)$ generated via the in-situ electroplating. The polarization range (potential window) was $1000 \mathrm{mV}$ in $0.01 \mathrm{~mol} \mathrm{~L}^{-1}$ hydrocholoric acid; the anodic limit is more positive than $\mathrm{Bi}$ - and $\mathrm{Sb}$-film electrodes due to the more positive oxidation potential of selenium but the polarization range is almost the same as those on both electrodes. A small and broad anodic response, as shown in Fig. 1 (line 2), was observed in the potential range of 200-500 $\mathrm{mV}$ for a solution of $500 \mu \mathrm{g} \mathrm{L}^{-1} \mathrm{Se}(\mathrm{IV})$ by scanning the potential in a positive direction following deposition at $-300 \mathrm{mV}$ for $180 \mathrm{~s}$. On the other hand, $\mathrm{Cu}(\mathrm{II})$ itself gives a small response at around $-100 \mathrm{mV}$ in absence of $\mathrm{Se}(\mathrm{IV})$. The anodic response due to $\mathrm{Cu}(\mathrm{II})$ was enhanced at a 5 -fold 
when $500 \mu \mathrm{g} \mathrm{L}^{-1} \mathrm{Se}(\mathrm{IV})$ was present (see Fig. 1). As can be seen from Fig. 2, a well-resolved Cu(II) peak at about $200 \mathrm{mV}$ was observed on the OSWASV curve for a test solution containing an excess amount of $\mathrm{Se}(\mathrm{IV})$ over $\mathrm{Cu}(\mathrm{II})$. Obviously, CuSe and its intermetallic analogues were formed at the deposition step onto the carbon substrate surface, giving rise to a subsequent $\mathrm{Cu}(\mathrm{II})$ stripping peak. OSWASV measurements at varying ppb-level concentrations revealed that the peak currents at about $200 \mathrm{mV}$ were directly proportional to the concentration of $\mathrm{Cu}$ (II) initially taken (see Fig. 2), which indicates that the proposed OSWASV method enables determination of traces $\mathrm{Cu}(\mathrm{II})$ in real samples.

Effect of experimental variables

Several experimental variables have been studied for the determination of $10.0 \mu \mathrm{g} \mathrm{L}^{-1} \mathrm{Cu}$ (II) by OSWASV using the in-situ plated Se-film carbon electrode. Fig. 3 illustrates the dependence of the $\mathrm{Cu}(\mathrm{II})$ response on hydrochloric acid concentration of the test solution. The $\mathrm{Cu}(\mathrm{II})$ response increased with increasing hydrochloride acid concentration up to $0.01 \mathrm{~mol} \mathrm{~L}^{-1}$, and then it decreased from 0.01 to $0.15 \mathrm{~mol} \mathrm{~L}^{-1}$. We further found that the addition of potassium chloride $\left(0.05 \mathrm{~mol} \mathrm{~L}^{-1}\right)$ showed maximum over the concentration range of $0-0.30 \mathrm{~mol} \mathrm{~L}^{-1}$, and that the reproducibility greatly improved. Consequently, a mixed supporting electrolyte of $0.01 \mathrm{~mol} \mathrm{~L}^{-1}$ hydrochloric acid and 0.05 mol L ${ }^{-1}$ potassium chloride was chosen as the most suitable concentrations.

The $\mathrm{Cu}(\mathrm{II})$ response increased linearly with increasing Se(IV) concentration up to $300 \mu \mathrm{g} \mathrm{L}^{-1}$, above which concentrations it remained almost constant (see Fig. 4). The $\mathrm{Cu}(\mathrm{II})$ peak potential, on the other hand, shifted to more positive directions with increased concentrations of Se(IV) taken. All subsequent experiments were conducted using a Se(IV) concentration of $500 \mu \mathrm{g} \mathrm{L}^{-1}$ in order to obtain 
a wider dynamic range of the $\mathrm{Cu}(\mathrm{II})$ calibration.

The effect of deposition potential on the $\mathrm{Cu}(\mathrm{II})$ anodic response was investigated over the range of -100 to $-600 \mathrm{mV}$ vs. $\mathrm{Ag} / \mathrm{AgCl}$. The results shown in Fig. 5 indicate that the $\mathrm{Cu}(\mathrm{II})$ response was constant in the potential range between -200 and $-500 \mathrm{mV}$. At potentials lower than $-500 \mathrm{mV}$, the anodic response decreased due to formation of $\mathrm{H}_{2} \mathrm{Se}$ evolved. Increased deposition times ranging from 60 to $360 \mathrm{~s}$ showed a linear relationship with the $\mathrm{Cu}(\mathrm{II})$ anodic response. Therefore, a deposition potential of $-300 \mathrm{mV}$ and a deposition time of $180 \mathrm{~s}$ were chosen in this study.

Calibration curve and detection limit

The calibration plots for the determination of $\mathrm{Cu}(\mathrm{II})$ by the proposed OSWASV method were constructed under the optimized experimental conditions. A linear relationship between the OSWASV peak current and $\mathrm{Cu}(\mathrm{II})$ concentration was obtained over the concentration range from 1.0 to $100 \mu \mathrm{g}$ $\mathrm{L}^{-1}: I=0.373 C+1.273\left(R^{2}=0.9936, I=\right.$ peak current in $\mu \mathrm{A} ; C=\mathrm{Cu}(\mathrm{II})$ concentration in $\left.\mu \mathrm{g} \mathrm{L}^{-1}\right)$. The detection limit calculated as $3 \sigma$ from a calibration point of $1.0 \mu \mathrm{g} \mathrm{L}^{-1} \mathrm{Cu}(\mathrm{II})$ was $0.2 \mu \mathrm{g} \mathrm{L}^{-1}$ for a deposition time of $180 \mathrm{~s}$, and the relative standard deviation was $2.3 \%(\mathrm{n}=8)$ for $10.0 \mu \mathrm{g} \mathrm{L}{ }^{-1} \mathrm{Cu}(\mathrm{II})$. This detection limit is comparable with those obtained by DPASV methods using the bismuth-film electrodes $[22,25]$.

Interference

The effect of foreign ions on the OSWASV determination of $10 \mu \mathrm{g} \mathrm{L}^{-1} \mathrm{Cu}(\mathrm{II})$ by the OSWASV 
method was investigated at a range of concentrations. The tolerance levels determined within $\pm 10 \%$ were $20 \mu \mathrm{g} \mathrm{L} \mathrm{L}^{-1}$ for $\mathrm{Sb}(\mathrm{III})$ and $50 \mu \mathrm{g} \mathrm{L} \mathrm{L}^{-1}$ for $\mathrm{Hg}(\mathrm{II}), \mathrm{Pb}(\mathrm{II}), \mathrm{Sn}(\mathrm{II}), \mathrm{Cd}(\mathrm{II})$ and $\mathrm{Mo}(\mathrm{VI})$, respectively. The presence of $\mathrm{Bi}(\mathrm{II})$ and $\mathrm{As}(\mathrm{II})$ was permissible at 10- and 30-fold amounts excess over $\mathrm{Cu}(\mathrm{II})$, respectively. No interference was also observed for $\mathrm{Na}(\mathrm{I}), \mathrm{Mg}(\mathrm{II}), \mathrm{Al}(\mathrm{III}), \mathrm{Ca}(\mathrm{II}), \mathrm{Zn}(\mathrm{II}), \mathrm{Fe}(\mathrm{III})$, $\mathrm{Co}(\mathrm{II}), \mathrm{Ni}(\mathrm{II}), \mathrm{Mn}(\mathrm{II}), \mathrm{V}(\mathrm{V})$ and $\mathrm{W}(\mathrm{VI})$ at $1000 \mu \mathrm{g} \mathrm{L}^{-1}$. Relatively less interferences from most metal ions investigated were observed except for $\mathrm{Sb}(\mathrm{III})$. Such anions as $\mathrm{NO}_{3}{ }^{-}, \mathrm{SO}_{4}{ }^{2-}$ and $\mathrm{H}_{2} \mathrm{PO}_{4}{ }^{-}$had no effect at $2.0 \mathrm{mg} \mathrm{L}^{-1}$. We should emphasize that the most remarkable feature of the proposed method is to offer such a better selectivity as well as high sensitivity.

Sample analysis

In order to assess the validity of the proposed OSWASV method, the two reference materials were analyzed by using standard addition method. The procedures for sample pretreatment are the same as those described earlier [14]. Figure 6 shows OSWASV curves obtained by successive addition of standard $\mathrm{Cu}(\mathrm{II})$ solution to a diluted sample solution of oyster tissue. The analytical results on four replicate determinations were $9.9 \pm 0.2 \mu \mathrm{g} \mathrm{L} \mathrm{L}^{-1}$ river water (The Japan Society for Analytical Chemistry) and for oyster tissue $64.8 \pm 1.6 \mathrm{~g} \mathrm{~g}^{-1}$ (NBS, USA), being coincident with the certified values $9.9 \pm 0.1$ $\mu \mathrm{g} \mathrm{L}^{-1}$ and $63.0 \pm 3.5 \mathrm{~g} \mathrm{~g}^{-1}$ respectively. Good accuracy and reliability are shown here; this makes us prompt further developments of possible analytical applications by the electrochemical stripping technique.

\section{Conclusions}


The application of the in-situ plated Se-film electrode was demonstrated for determining traces of $\mathrm{Cu}$ (II) by the proposed anodic stripping method using in-situ co-deposition of $\mathrm{Se}(\mathrm{IV})$ and $\mathrm{Cu}$ (II) onto a plastic formed carbon graphite electrode. The promising characteristic of the Se-film electrode is its wider positive potential range accessible than the $\mathrm{Bi}$ - and $\mathrm{Sb}$-films; it rather resembles gold-based electrodes in respect of the polarization range. Thus, this Se film electrode is expected to offer another type of "mercury-free" electrode for stripping analysis of metals or organic materials although it has a poor electronic conducting property.

\section{References}

1. Wang J, Stripping Analysis, VCH publishers, Deefield Beach, FL, 1985.

2. Florence TM (1970) Anodic stripping voltammetry with a glassy carbon electrode mercury-plated in situ. J Electroanal Chem 27:273

3. Wang J, Lu J, Hocevar SB, Farias PAM, Ogorevic B (2000) Bismuth-coated carbon electrodes for anodic stripping voltammetry. Anal Chem 72:3218

4. D. Demetriades, A. Economou, A. Voulgaropoulos (2004) A study of pencil-lead bismuth-film electrodes for the determination of trace metals by anodic stripping voltammetry. Anal Chim Acta 519: 167

5. Legeai S, Soropogui K, Cretinon M, Vittori O, Oliveria AHD, Barbier F, Loustalot MFG (2005) Economic bismuth-film microsensor for anodic stripping analysis of trace heavy metals using differential pulse voltammetry. Anal Bioanal Chem 383:839 
6. Legeai S, Bois S, Vittori O (2006) A copper bismuth film electrode for adsorptive cathodic stripping analysis of trace nickel using square wave voltammetry. J Electroanal Chem 591:93

7. Hocevar SB, Svancara I, Ogorevc B, Vytras K (2007) Antimony film electrode for electrochemical stripping analysis. Anal Chem 79:8639

8. Kokkinos C, Economou A, Raptis I, Speliotis T (2009) Novel disposable microfabricated antimony-film electrodes for adsorptive stripping analysis of trace Ni(II). Electrochem Commun 11: 250

9. Korolczuk M, Tyszczuk K, Grabarczk M (2006)Adsorptive stripping voltammetry of nickel and cobalt at in situ plated lead film electrode. Electrochem Commun 587:1185

10. Zhu WW, Li NB, Luo HQ (2007) Simultaneous determination of chromium(III) and cadmium(II) by differential pulse anodic stripping voltammetry on a stannum film electrode. $72: 1733$

11. Wang J, Lu JM, Kirgoz UA, Hocevar SB, Ogorevc B (2001) Insight into the anodic stripping voltammetric behavior of bismuth film electrodes. Anal Chim Acta 434:29

12. Korolczuk M, Moroziewicz A, Grabarczyk M (2005) Determination of subnanomolar concentrations of cobalt by adsorptive stripping voltammetry at a bismuth film electrode. Anal Bioanal Chem 382:1678

13. Wang J, Lu JM (2000) Bismuth film electrodes for adsorptive stripping voltammetry of trace nickel. Electrochem Commun 2:390

14. Long J, Nagaosa Y (2007) Cathodic stripping voltammetric determination of arsenic(III) with in situ plated bismuth-film electrode using the catalytic hydrogen wave. Anal Chim Acta 593:1

15. Long J, Nagaosa Y (2007) Determination of selenium(IV) by catalytic stripping voltammetry with an in situ plated bismuth-film electrode. Anal Sci 23:1343 
16. Wang J (2005) Stripping analysis at bismuth electrodes. Electroanalysis 17:1341

17. Economou A (2005) Bismuth-film electrodes: recent developments and potentialities for electroanalysis. Trends Anal Chem 24:334

18. Kokkinos C, Economou (2008) A stripping analysis at bismuth-based electrodes. Current Anal Chem 4: 183

19. Svancara I, Baldrianova L, Tesarova E, Hocevar SB, Elsuccary SAA, Economou A, Sotiropoulos S, Ogorevc B, Vytras K (2008) Recent advances in anodic stripping voltammetry with bismuth-modified carbon paste electrodes. Electroanalysis 18:177

20. Proir C, Lenehan CE, Walker GS (2007) Utilising gallium for enhanced electrochemical copper analysis at the bismuth film electrode. Anal Chim Acta 598:65

21. Prior C, Lenehan CE, Walker GS (2006) Enhanced resolution of copper and bismuth by addition of gallium in anodic stripping voltammetry with the bismuth film electrode. Electroanalysis 18:2486 22. Pacheco WF, Miguel WM, Ramos GV, Cardoso CE, Farias PAM, R.Q. Aucelio RQ (2008) Use of hydrogen peroxide to achieve interference-free stripping voltammetric determination of copper at the bismuth-film electrode. Anal Chim Acta 625:22

23. Takeuchi RM, Santos AL, Padilha PD, Stradiotto NR (2007) Copper determination in ethanol fuel by differential pulse anodic stripping voltammetry at a solid paraffin-based carbon paste electrode with 2-aminothiazole organofunctionalized silica. Talanta 71:771

24. Honeychurch KC, Hawkins DM, Hart JP, Cowell DC (2002) Voltammetric behaviour and trace determination of copper at a mercury-free screen-printed carbon electrode. Talanta 57:565

25. Bonfil Y, Brand M, Eisner EK (1999) Determination of sub-mg $\mathrm{L}^{-1}$ concentrations of copper by anodic stripping voltammetry at the gold electrode. Anal Chim Acta 387:85 
26. Ivanov DK, Poznyak CK, Osipovicch NP, Stel'tsov EA (2004) Electrochemical formation of amorphous selenium films doped by lead selenide nanoparticles. Russ J Electrochem 40:1044

27. Dergacheva MB, Chaikin VV, Grigor'eva VP, Pantileeva EP (2004) Electrodeposition of CuSe $\mathrm{x}_{\mathrm{x}}$ compounds onto carbon-containing electrodes. Russ J App Chem 77:1273

28. Riveros G, Henriquez R, Cordova R, Schrebler R, Dalchiele EA, Gomez H (2001) Electrochemical study concerning the deposition of dopper on selenium covered gold electrodes J Elctroanal Chem $504: 160$

29. Yang YJ, Hu S (2009) Galvanic synthesis of copper selenides $\mathrm{Cu}_{2-\mathrm{x}} \mathrm{Se}$ and CuSe in alkaline solution selenosulfate aqueous solution. J Solid State Electrochem 13:477

30. Lange B, Scholz F (1997) Cathodic stripping voltammetric determination of selenium(IV) at a thin-film mercury electrode in a thiocyanate-containing electrolyte. Fresenius J Anal Chem 358:736

31. Sladkov V, David F, Fourest B (2003) Copper-mercury film electrode for cathodic stripping voltammetric determination of Se(IV). Anal Bioanal Chem 375:300

32. Zaitsev NK, Osipova EA, Fedulov, Eremenko EA, Dedov AG (2006) Determination of selenium(IV) by cathodic stripping voltammetry using a copper-modified mercury-film electrode modified with copper. J Anal Chem 61:83 


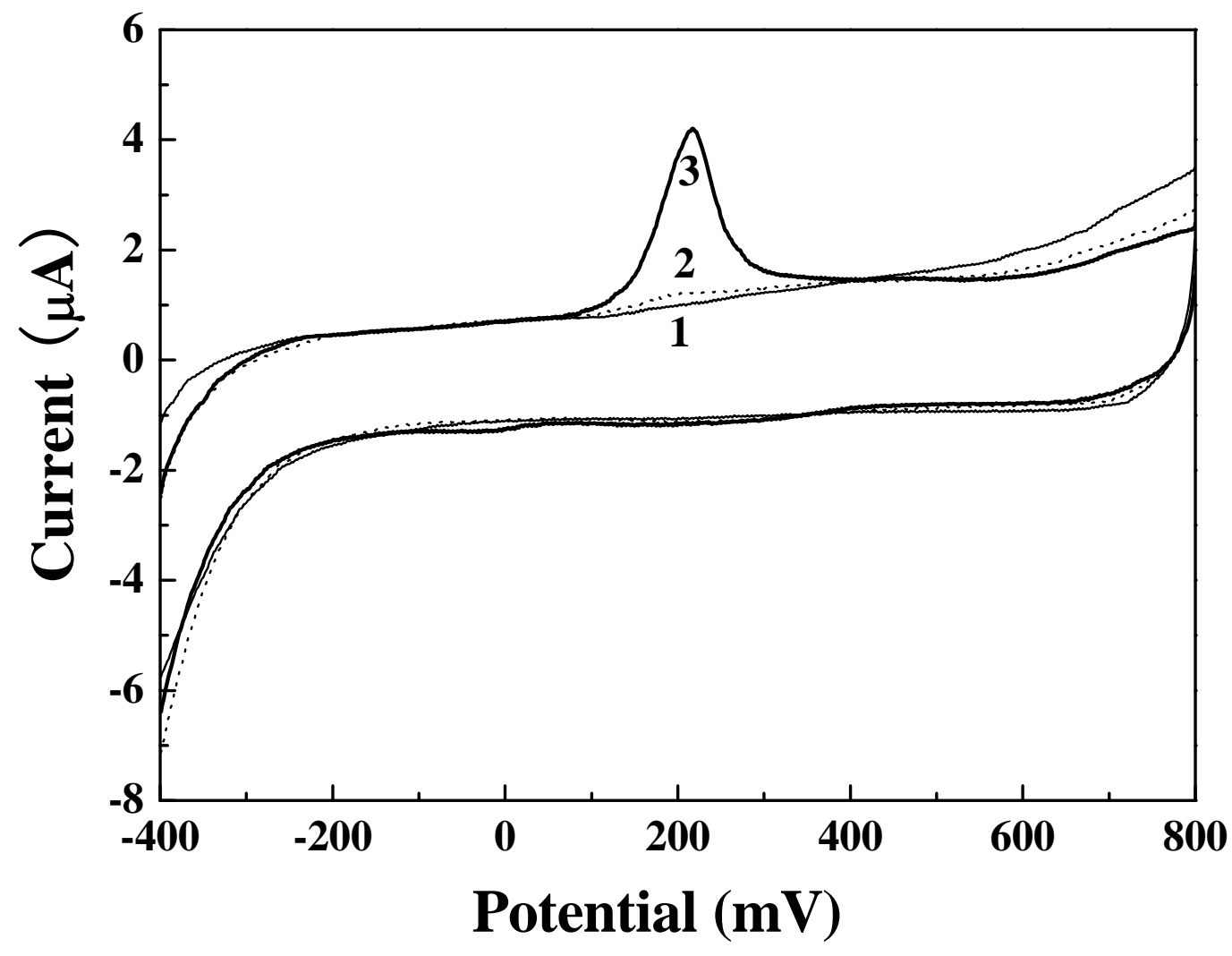

Fig. 1 


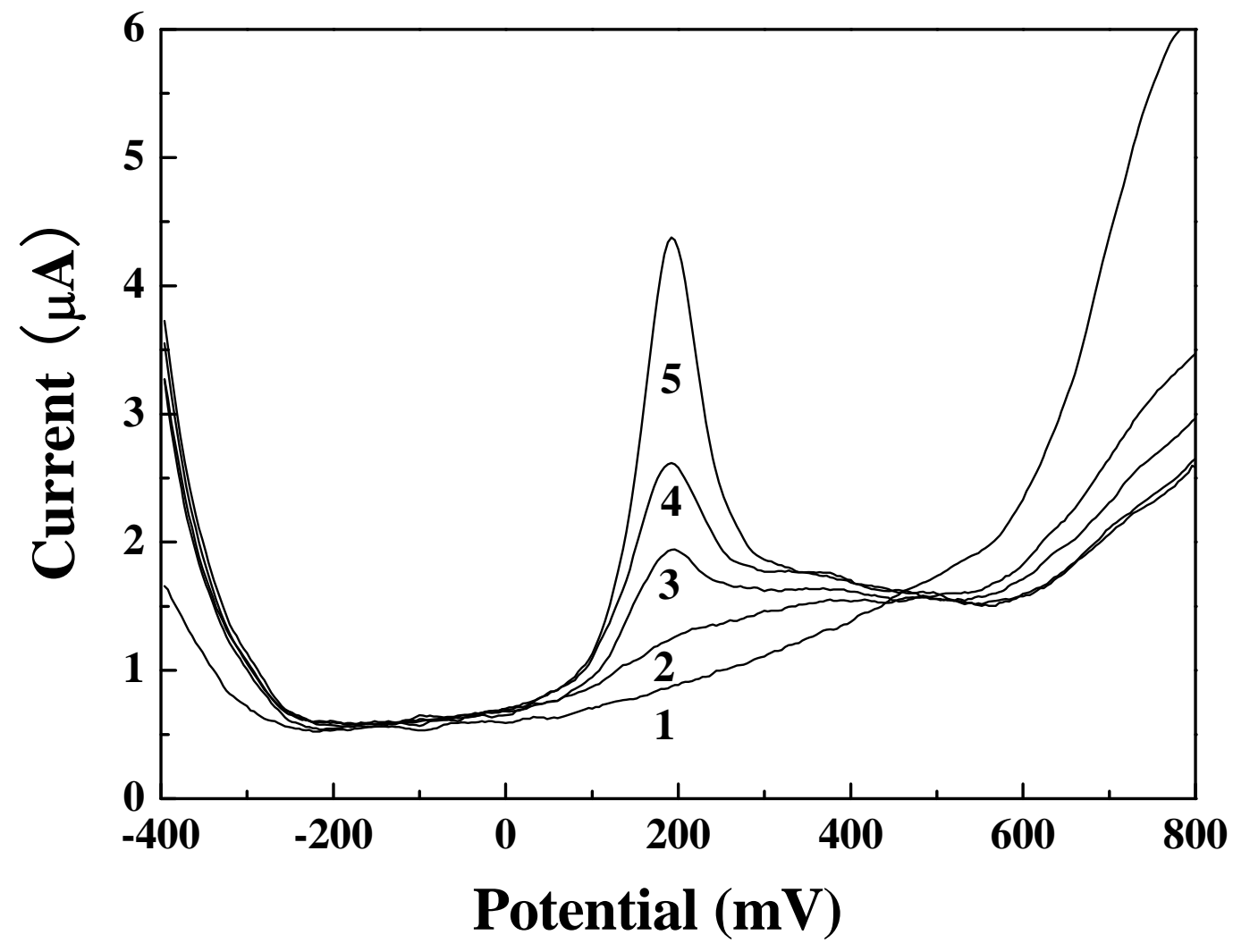

Fig. 2 


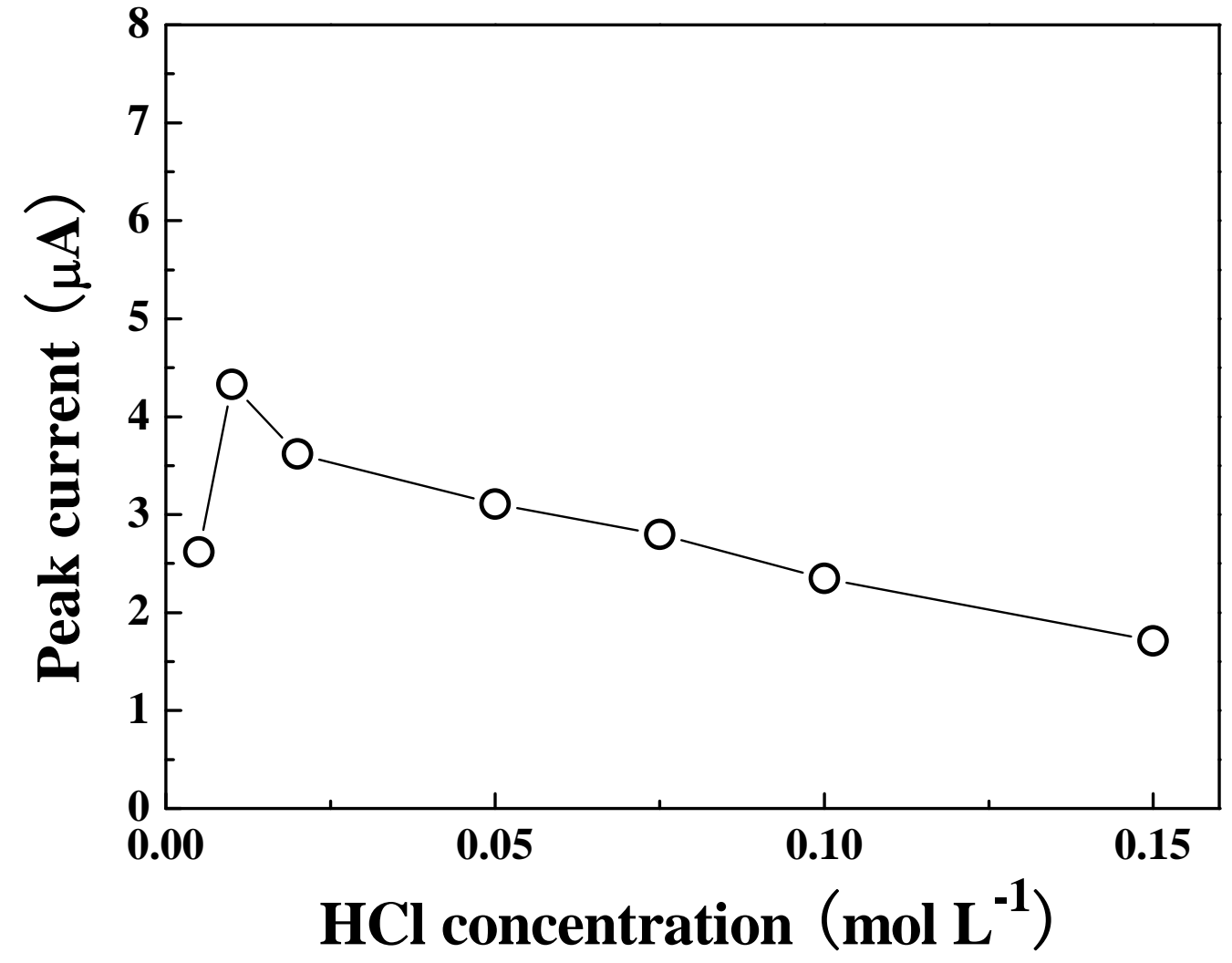

Fig. 3 


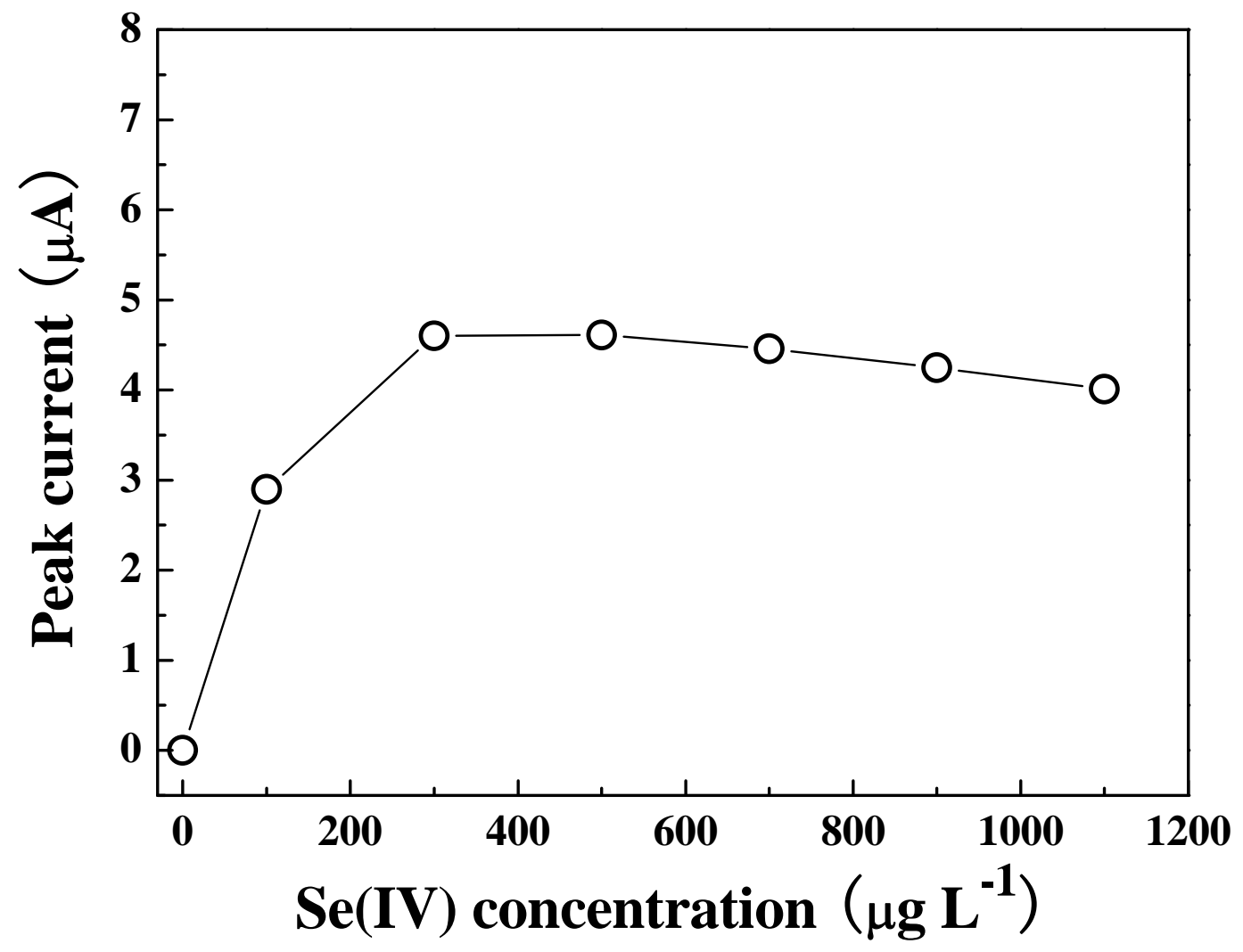

Fig. 4 


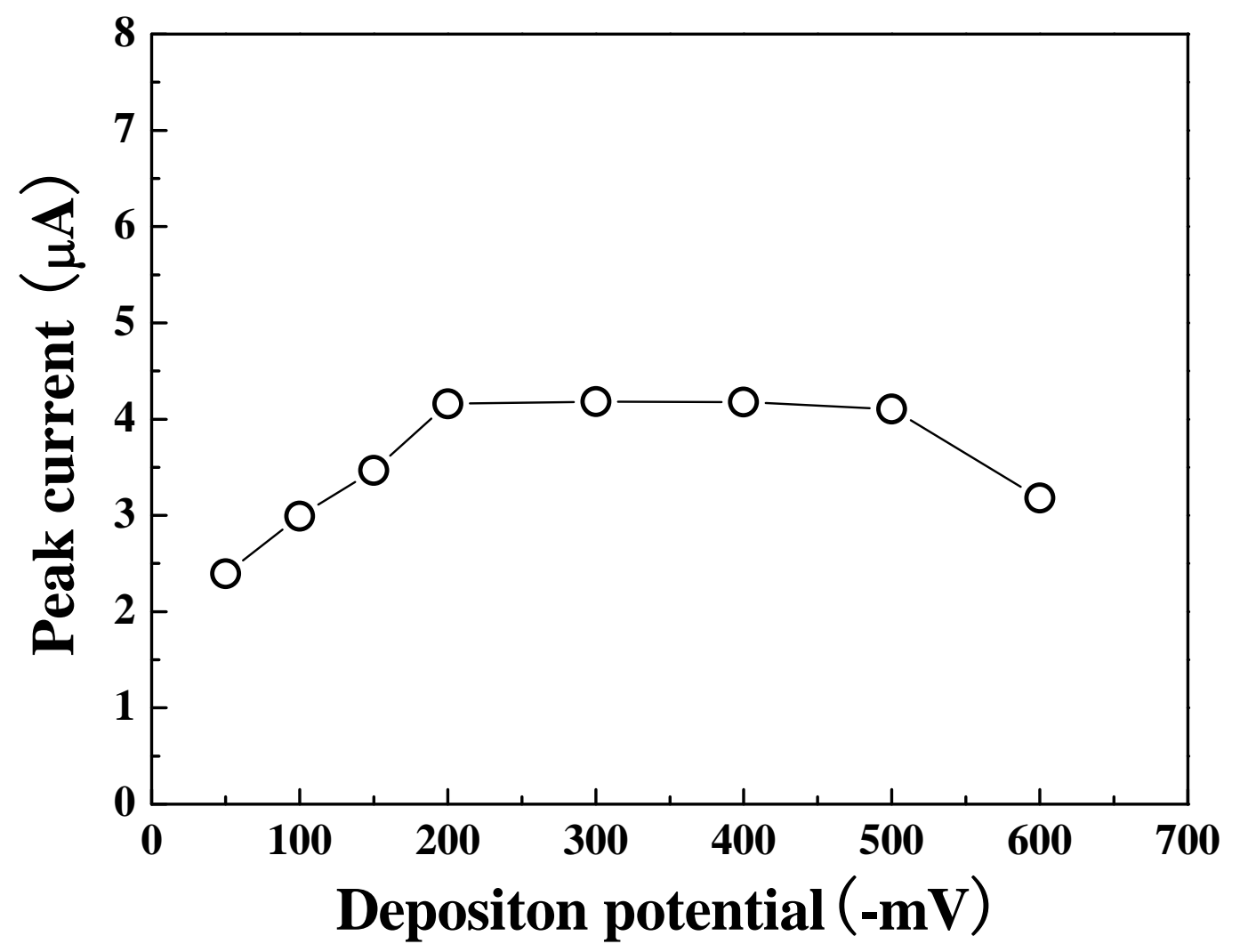

Fig. 5 


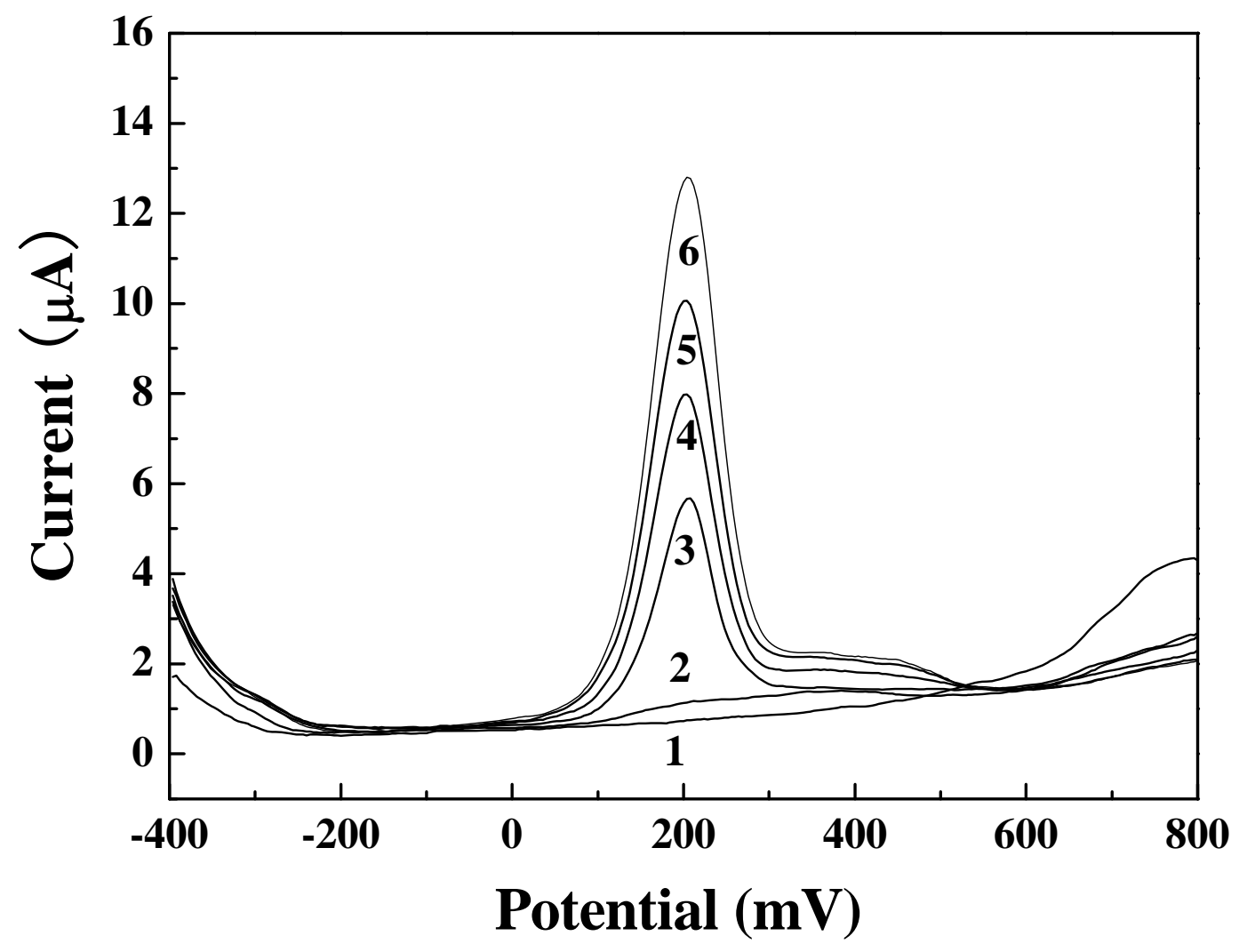

Fig. 6 


\section{Figrue captions}

Fig. 1. Cyclic voltammograms. (1) $0.01 \mathrm{~mol} \mathrm{~L}^{-1} \mathrm{HCl}+0.05 \mathrm{~mol} \mathrm{~L}^{-1} \mathrm{KCl}$, (2) (1) $+500 \mu \mathrm{g} \mathrm{L}^{-1} \mathrm{Se}(\mathrm{IV})$, (3) (2) $+10 \mu \mathrm{g} \mathrm{L}^{-1} \mathrm{Cu}(\mathrm{II})$. Deposition potential, $-300 \mathrm{mV}$; deposition time, $180 \mathrm{~s}$; scan rate $\left(\mathrm{mV} \mathrm{s}^{-1}\right)$, 100.

Fig. 2. OSWASV curves. (1) $0.01 \mathrm{~mol} \mathrm{~L}^{-1} \mathrm{HCl}+0.05 \mathrm{~mol} \mathrm{~L}^{-1} \mathrm{KCl}$, (2) (1) $+500 \mu \mathrm{g} \mathrm{L} \mathrm{L}^{-1} \mathrm{Se}(\mathrm{IV})$, (3) (2) $+1 \mu \mathrm{g} \mathrm{L}{ }^{-1} \mathrm{Cu}(\mathrm{II})$, (4) (2) $+2 \mu \mathrm{g} \mathrm{L}{ }^{-1} \mathrm{Cu}(\mathrm{II})$, (5) (2) $+5 \mu \mathrm{g} \mathrm{L}^{-1} \mathrm{Cu}$ (II). Deposition potential, $-300 \mathrm{mV}$; deposition time, $180 \mathrm{~s}$.

Fig. 3. Effect of hydrochloric concentration on OSWASV peak current. $500 \mu \mathrm{g} \mathrm{L}^{-1} \mathrm{Se}(\mathrm{IV})+10 \mu \mathrm{g} \mathrm{L}^{-1}$ $\mathrm{Cu}(\mathrm{II})$. Deposition potential, $-300 \mathrm{mV}$; deposition time, $180 \mathrm{~s}$.

Fig. 4. Effect of Se(IV) concentration on OSWASV peak current. $0.01 \mathrm{~mol} \mathrm{~L}^{-1} \mathrm{HCl}+0.05 \mathrm{~mol} \mathrm{~L}^{-1}$ $\mathrm{KCl}+500 \mu \mathrm{g} \mathrm{L}{ }^{-1} \mathrm{Se}(\mathrm{IV})+10 \mu \mathrm{g} \mathrm{L}{ }^{-1} \mathrm{Cu}(\mathrm{II})$. Deposition potential, $-300 \mathrm{mV}$; deposition time, $180 \mathrm{~s}$.

Fig. 5. Effect of deposition potential on OSWASV peak current. $0.01 \mathrm{~mol} \mathrm{~L}^{-1} \mathrm{HCl}+0.05 \mathrm{~mol} \mathrm{~L}^{-1} \mathrm{KCl}$ $+500 \mu \mathrm{g} \mathrm{L}^{-1} \mathrm{Se}(\mathrm{IV})+10 \mu \mathrm{g} \mathrm{L}{ }^{-1} \mathrm{Cu}(\mathrm{II})$. Deposition time, $180 \mathrm{~s}$.

Fig. 6. OSWASV curves for $\mathrm{Cu}(\mathrm{II})$ determination of Oyster tissue. (1) $0.01 \mathrm{~mol} \mathrm{~L}^{-1} \mathrm{HCl}+0.05 \mathrm{~mol} \mathrm{~L}^{-1}$ $\mathrm{KCl}$, (2) (1) + $500 \mu \mathrm{g} \mathrm{L}^{-1} \mathrm{Se}(\mathrm{IV})$, (3) (2) + real sample, (4-6) (3) + successive addition of $3 \mu \mathrm{g} \mathrm{L}^{-1}$ $\mathrm{Cu}(\mathrm{II})$. Deposition potential, $-300 \mathrm{mV}$; deposition time, $180 \mathrm{~s}$. 